\title{
Eurostudia
}

\section{Seductive Atmospheres, Conflicting Symbols: Religious Landmark Buildings in Diverse Societies}

\section{Silke Steets}

Volume 12, numéro 1, 2017

Religion and Space: Tensions and Negotiations in Everyday Life La religion et l'espace : tensions et négociations au quotidien Religion und Raum: Spannungen und Aushandlungen im Alltag

URI : https://id.erudit.org/iderudit/1041666ar

DOI : https://doi.org/10.7202/1041666ar

Aller au sommaire du numéro

\section{Éditeur(s)}

Le Centre canadien d'études allemandes et européennes

ISSN

1718-8946 (numérique)

Découvrir la revue

Citer cet article

Steets, S. (2017). Seductive Atmospheres, Conflicting Symbols: Religious Landmark Buildings in Diverse Societies. Eurostudia, 12(1), 125-135. https://doi.org/10.7202/1041666ar
Résumé de l'article

Informed by the sociology of knowledge, this paper understands buildings as "material objectivations" that continuously "act back" upon their users. It examines the following question: Why are the discussions about constructing new (religious) landmark buildings, or the rebuilding of historical ones, so emotionally charged? Using the debate about a proposed golden cross on top of the reconstruction of the Prussian City Palace in Berlin as a starting point, this article studies buildings on two levels: the level of bodily experience, on which they unfold their seductive features, and the level of - often conflicting symbolic inscription. The analysis shows that religious landmark buildings, such as churches or mosques, use specific means of expression to stimulate the experience of the "numinous." As a result, they are often loaded with strong emotions and feelings of belonging or dis-belonging. As religious communities increasingly become fragmented in diverse societies, symbolic recognition in landmark projects appears to be a deeply political concern.
Tous droits réservés $@$ Le Centre canadien d'études allemandes et européennes, 2017
Ce document est protégé par la loi sur le droit d'auteur. L'utilisation des services d’Érudit (y compris la reproduction) est assujettie à sa politique d'utilisation que vous pouvez consulter en ligne.

https://apropos.erudit.org/fr/usagers/politique-dutilisation/ 


\title{
Silke Steets
}

Leipzig University

\begin{abstract}
:
Informed by the sociology of knowledge, this paper understands buildings as "material objectivations" that continuously "act back" upon their users. It examines the following question: Why are the discussions about constructing new (religious) landmark buildings, or the rebuilding of historical ones, so emotionally charged? Using the debate about a proposed golden cross on top of the reconstruction of the Prussian City Palace in Berlin as a starting point, this article studies buildings on two levels: the level of bodily experience, on which they unfold their seductive features, and the level of - often conflicting - symbolic inscription. The analysis shows that religious landmark buildings, such as churches or mosques, use specific means of expression to stimulate the experience of the "numinous." As a result, they are often loaded with strong emotions and feelings of belonging or dis-belonging. As religious communities increasingly become fragmented in diverse societies, symbolic recognition in landmark projects appears to be a deeply political concern.
\end{abstract}

In May 2017, a press conference by the Förderverein Berliner Stadtschloss, an association dedicated to supporting the reconstruction of the Prussian City Palace in Berlin, sparked a fierce discussion about national identity across Germany. The debate was triggered by the Förderverein's cheerful announcement that, thanks to a generous donation, the reconstruction not only of the baroque facades of the palace (for which the association initially had been collecting money) but also of its historical cupola with a golden cross on top would finally be possible. What followed the announcement was a highly emotional debate covered by newspapers, radio features, and telecasts alike about the possible meaning of the cross in contemporary Germany. 


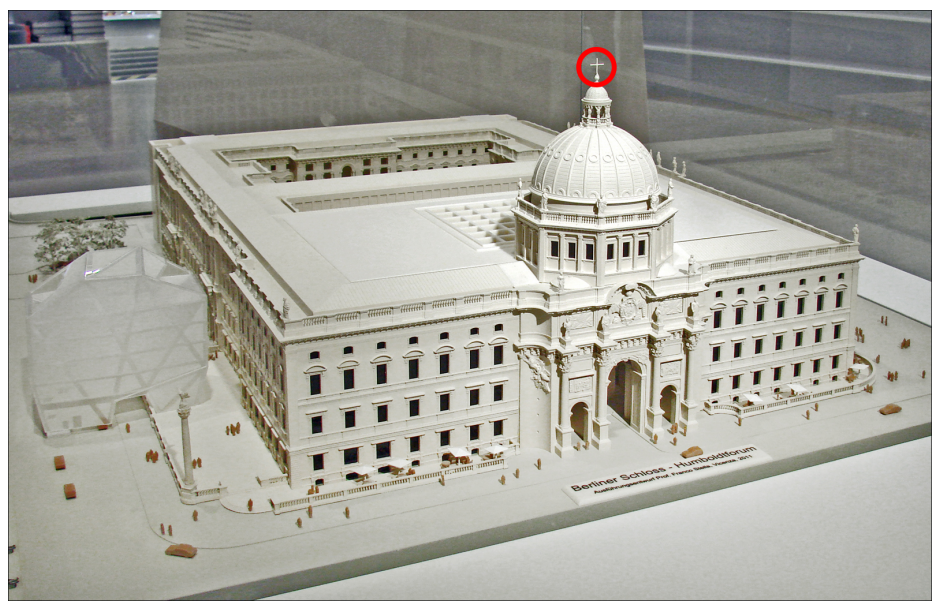

Picture 1: Model of the reconstructed Prussian City Palace (including the cross on its cupola) by Franco Stella, winner of the architectural competition, 2008 (Photography: Jean-Pierre Dalbéra, Source: de.wikipedia.org, CC BY 2.0, red circle added)

In order to better understand the discussions, one needs to know that the Prussian City Palace used to be the royal and imperial palace that dominated Berlin's historical center and served as the residence of the Kings of Prussia and the German Emperors (see picture 2a). After the partial destruction of the palace during World War II, the government of the German Democratic Republic (GDR) decided to tear what was left of the building down completely and to build the so-called Palace of the Republic on its land (see picture 2b). Built in the 1970s, the iconic building served as the seat of the Volkskammer, the GDR's parliament, and also housed spaces for various cultural purposes, including a theatre, a bowling alley, and a discothèque. After the wall came down in 1989, heated discussions about the future of the Palace of the Republic started and even intensified after the building got an asbestos clean-up in 2003, leaving it in the condition of a raw shell construction. Under the headline "Zwischenpalastnutzung," the site then served as a space for several spectacular art interventions until it eventually was demolished in 2008 to make room for the reconstruction of the Prussian City Palace. The new building is currently under construction and will probably be completed in 2019. Under the name "Humboldt Forum" it will house the Ethnological Museum of Berlin and the Museum of Asian Art. Its self-proclaimed aim is to form a cultural world center similar to the British Museum in London or the Centre Pompidou in Paris. 

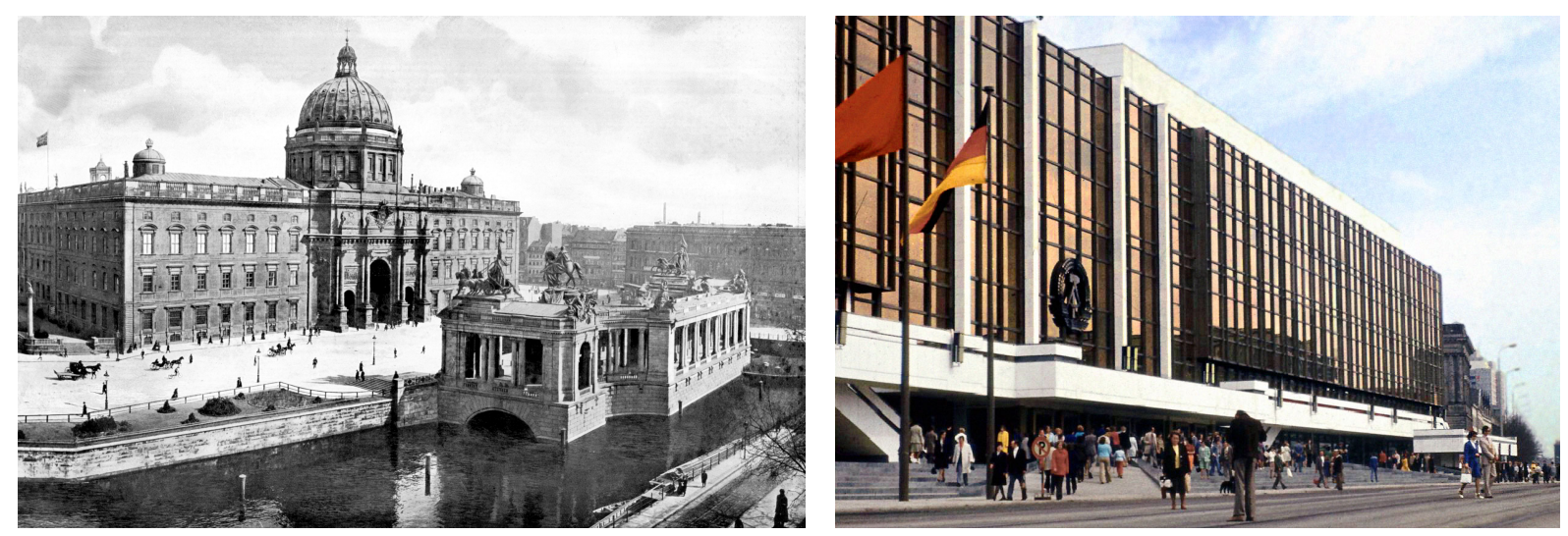

Picture 2a: Prussian City Palace, West facade with classicist copula and cross on the top, around 1900 (Photography: unknown, Source: Wikimedia Commons)

Picture 2b: Palace of the Republic, around 1980 (Photography: Lutz Schramm, Source: lutzschramm.de, CC BY-SA 2.0)

There is an at least two-decade long history of conflicts including discussions about what to do with this contested site and on how to symbolize a contemporary notion of "Germany" at the very heart of the country's capital. Looking at this debate as a whole would go far beyond my assignment here (for an overview see Hennet 2007). Instead, I will focus on the arguments formulated by politicians and representatives of civil society around the question of whether there should be a golden cross on top of the reconstructed City Palace, the Humboldt-Forum.

The range of arguments against the cross is rather wide: Berlin's local minister for cultural affairs, Klaus Lederer of the party DIE LINKE, for instance, figures that the cross is actually rather meaningless, since more than two thirds of Berlin's population are not affiliated with any religion (Habermalz 2017). The NGO Stiftung Zukunft Berlin goes a step further and argues that the cross will possibly jeopardize intercultural and interreligious dialogues by asking the following question: "How can we succeed in creating an open exchange between different religious as well as between religious and secular worldviews if the cross on top of the cupola already sets the course?" (Stiftung Zukunft Berlin 2017). The probably oddest contribution to the discussion comes from the Association of German Humanists: instead of a golden cross on top of the building, they propose to put a golden microscope to honour the Prussian naturalist and explorer Alexander von Humboldt, after whom the future museum complex is named (Habermalz 2017). 
Those who are in favour of the project basically take two positions: a rather technical and worldly argument considering the cross simply as part of a historically truthful reconstruction of the City Palace - without making it a big issue (cf. Focus Online 2017). However, one may add that the original cross was only installed on the cupola in 1854, after the counterinsurgency of the German Revolution of 1848/49 by King Frederick William IV. Historically, it rather stands for the authoritative and, therefore, highly debatable Prussian unity of state and church. The Catholic archbishop of Berlin, Heiner Koch, together with a few others, presents a second position: he welcomes the cross as "a blissful sign of the Christian faith for all human beings" (rbb 2017). Similarly, Germany's federal minister of culture, Monika Grütters, counters the opponents of the cross with the statement that an exchange with other cultures must be possible without denying one's own Christian roots (rbb 2017).

To sum up, the planned cross on top of Germany's most contested architectural project works as the catalyst for a process of self-identification: Is Germany still a Christian society? Or is it a society based on a Judeo-Christian tradition? Or is it, rather, a secularizing society that used to be a Christian one? If so, what could the cross then mean for such a society? From an architecturalsociological perspective one might ask: Why are the discussions conducted around the construction of new (religious) landmark buildings, or the reconstruction of historical ones, often so emotionally charged? In order to answer this question, I will use a mixture of phenomenological and sociological perspectives, some of which have influenced Peter L. Berger and Thomas Luckmann in their by-now classic work The Social Construction of Reality (1967 [1966]) and others that have been influenced by the sociology of knowledge they formulated.

\section{Architecture as a Social Construction}

In my own work on the sociology of architecture I draw on Berger and Luckmann's approach to show how it can be applied to the realm of materiality, that is the world of things, technical artefacts - and buildings (Steets 2015). The idea of "material objectivations" is at the heart of my analysis (Steets 2016). In Berger and Luckmann's theory, "objectivations" refer to "products of human activity that are available both to their producers and to other men as elements of a common world" (1967 [1966]: 49). Objectivations continuously "act back" upon their producers and may take many forms: from everyday routines (as 
relatively fixed behavioural patterns), to commonly recognized linguistic expressions (that we all need to use in order to make ourselves understood), all the way to institutions that structure social life. Berger and Luckmann stress that objectivations are always characterized by the fact that they are "thinglike" in a Durkheimian sense - with "thing-like" in quotation marks. Although it may not be possible to touch routines, linguistic expressions or institutions, these phenomena are still "real," since they outlive particular social situations as routines, language or institutions. In my own work, I take the idea of the "thing-likeness" of objectivations as a starting point for a sociology of knowledge-based analysis of "things" that are not only socially, but also physically real - such as material objects or buildings. In other words, I removed the quotation marks from the formula "thing-likeness" and took Berger and Luckmann literally (cf. Steets 2015, 2016). Objects and buildings can thus be conceptualized as part of the social world through both their materiality and their symbolism. Put differently, "material objectivations," such as buildings, become "social facts" in a Durkheimian sense, to the extent that they are visible, touchable, and sensible.

In order to show the fruitfulness of this theoretical perspective, in the next two sections I will focus on the social reality of religious landmark buildings on two levels: 1) the level of bodily experience on which they unfold their seductive power and 2) the level of symbolic inscription on which they often provoke heated debates. After bringing together these two levels, I will return to the Prussian City Palace in Berlin and to the question of whether it should be equipped with a cross on its top.

\section{Seductive Atmospheres}

In his book The Architecture of Happiness (2006), Swiss philosopher Alain de Botton quite impressively describes a situation when he once visited Westminster Cathedral in London. 


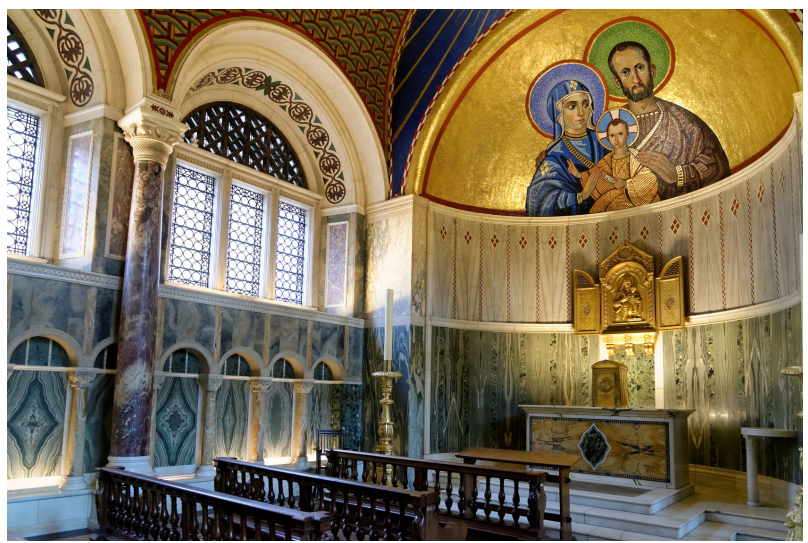

Picture 3: The Chapel of St. Joseph in Westminster Cathedral (Photography: ani_snimki, Source: fotolia.com)

"After ten minutes in the cathedral, a range of ideas that would have been inconceivable outside began to assume an air of reasonableness. Under the influence of the marble, the mosaics, the darkness and the incense, it seemed entirely probable that Jesus was the son of God and had walked across the Sea of Galilee. In the presence of alabaster statues of the Virgin Mary set against rhythms of red, green and blue marble, it was no longer surprising to think that an angel might at any moment choose to descend through the layers of dense London cumulus, enter through a Window in the nave, blow a golden trumpet and make an announcement in Latin about a forthcoming celestial event. Concepts that would have sounded demented forty metres away, [...] [that is, outside the cathedral] had succeeded - through a work of architecture - in acquiring supreme significance and majesty" (de Botton 2006: 109-111).

Alain de Botton's account points to a phenomenon one could call the aesthetic staging of the "numinous" in sacred architecture. Sacred or religious architecture - and this holds true not only for examples from the Christian world - is based upon the imagination that spatial and built environments are crucial to religious experiences. In order to explain how this works, let me make a few comments on the phenomenology of religion.

In his major publication Das Heilige (2013 [1917]), German theologian and philosopher Rudolf Otto is concerned with the fundament of religious experience, which - for him - is the experience of the "numinous." The "numinous," a synonym of "the holy," cannot be verified by reason. According to Otto, it is a moment in human experience that is irrational and transcendent, and thereby mediated bodily as a feeling of intense excitement. This excitement can be overwhelmingly positive - think of the experience of the magical, or the sublime - as well as truly angst-inducing, for which an impression of 
awfulness or overpoweringness would be examples. According to Otto, religious traditions use different "means of expression" (ibid.: 79); among them, and especially important, is architecture. In his book he describes a whole range of constructive elements that are qualified to induce the experience of the "numinous," such as the contrast between the giant and the tiny, which can be interpreted as an alteration of the contrast between the universe (gigantic) and the human being (tiny) - a central motif in almost any religion. With regard to architecture, this contrast can be realized vertically as well as horizontally.

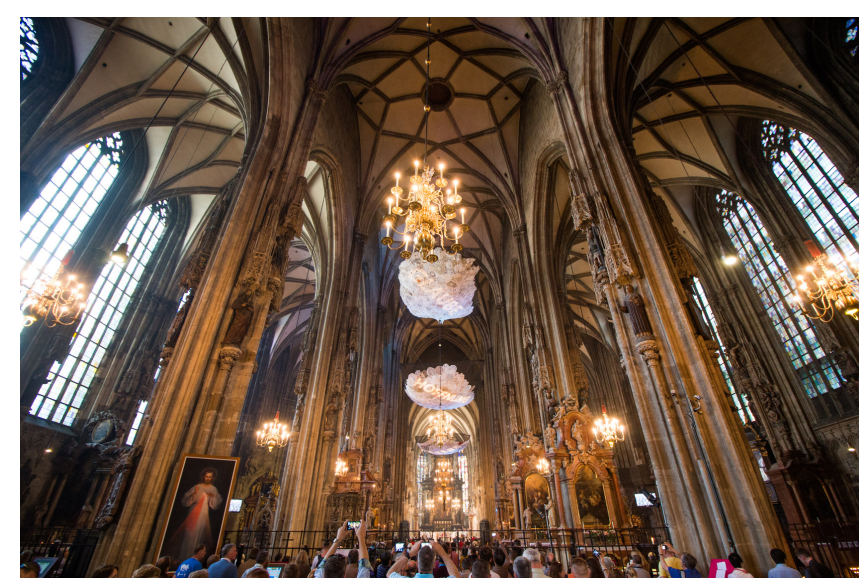

Picture 4: St. Stephen's Cathedral Vienna (Photography: Patrick Daxenbichler, Source: fotolia.com)

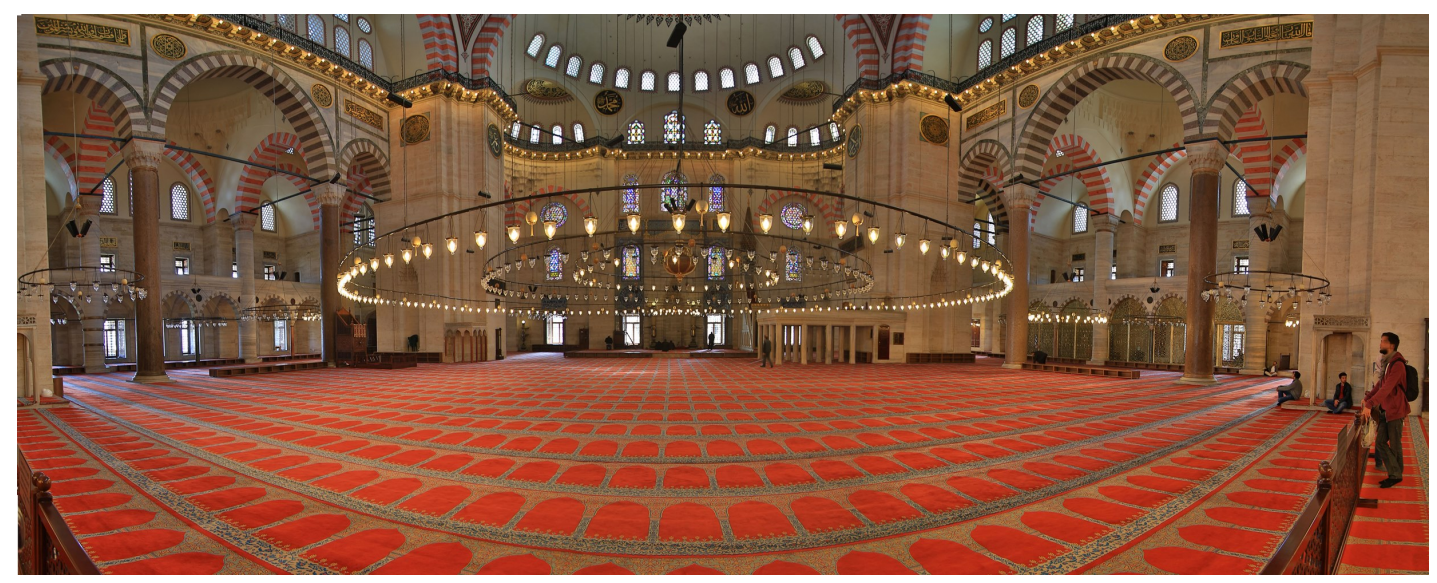

Picture 5: Süleymaniye Mosque Istanbul (Photography: unknown, Source: guidesistanbul.com)

While Western architecture imposes on us the impression that we are tiny creatures through creating breathtaking vertical spaces - think of St. Stephen's cathedral in Vienna (see picture 4) for example - Oriental architecture is more based on the magical virtue of vastness and emptiness as one can see 
in the example of Süleymaniye mosque in Istanbul (see picture 5). According to Otto, the experience of silence, darkness (as the visual equivalent to silence) as well as the contrasting play of light and darkness would evoke similar effects. Otto writes: "Beyond dispute art has here a means of creating a unique impression - that of the magical apart from and independent of reflection" (1936 [1917]: 69). ${ }^{1}$ What we can learn from Otto's remarks is the ways religious landmark buildings create atmospheres that seduce their visitors on a bodily and sensory level. However, such buildings also refer to and - as we will see actually realize symbolic universes. They contribute to the formation of different (and sometimes divergent) religious collectives.

\section{Conflicting Symbols}

British sociologist Paul Jones has devoted much of his work to the processes of collective identity formation in diverse societies. He argues that architecture and more specifically "landmark buildings" - have been an important cultural expression of collective identities (cf. Delanty and Jones 2002; Jones 2006). Landmark buildings are pieces of architecture that stand out from their near environment and are often visible from long distances. They are in the very sense of the word significant or meaningful, that is, through their form, height, the material they consist of, or the place they are located in. St. Stephen's Cathedral in Vienna, the Süleymaniye Mosque in Istanbul as well as the Prussian City Palace in Berlin are prime examples of landmark buildings in that sense. In his work, Jones shows that these buildings often provide a space for contestations associated with collective identities. Obviously, it is these buildings' capacity to represent abstract values, such as "nation," "freedom," "Christianity," "Germany," etc., "materially, and indeed often literally "in concrete," which offers a tangible focus for identity discourses of many kinds" (Jones 2006: 549, emphasis added). Following Jones (ibid.: 553), the interesting question for sociologists is: how do symbols of a collective develop, and how do we come to recognize ourselves as a "we"?

Processes of "architecturing identities" - to use Jones's (2006: 549) expression - turn out to be even more crucial against the background of late modernity and the increasing fragmentation of cultural communities. In diverse

\footnotetext{
1 "Es ist kein Zweifel, daß die Kunst hier Mittel hat, ohne Reflexion einen ganz art-besonderen Eindruck hervorzurufen, nämlich eben den des 'Magischen'” (Otto 2013 [1917]: 86).
} 
societies, the idea of the "nation," for instance, is not something that can be taken for granted. The discussions around the reconstruction of the Prussian City Palace in Berlin unveil contestations of what "Germany" means. The question whether today's Germany is still a Christian society or rather a society based on Judeo-Christian values, or even a mainly secularized society with a cultural history that, among others, has Christian flavour is obviously highly controversial. Similarly intense and emotionally loaded discussions can be observed in German cities where Muslim communities campaign for the construction of landmark mosque buildings. These debates reveal that the state's ability to control and stabilize identities today is challenged by fragmentations and re-appropriations of collective identities. According to the German Census database (2011), only about 55\% of the population in Germany currently belong to the Catholic or the Protestant Church; about 5\% are Muslims; the largest statistical group is the "nones" with $35 \%$, which designates people who do not have any religious affiliation. However, as we know from recent research in Germany and other countries (cf. Wohlrab-Sahr, Karstein and Schmidt-Lux 2009, Woodhead 2016), only a small number of the "nones" are atheists and many of them call themselves "spiritual" in one way or another. We are rather confronted with a religiously diverse situation than a linear process of secularization. Applied to the topic of religious landmark buildings, one can conclude that in an era of diverse cultures within a nation, attempts made by the government or other actors to reinvent state-driven collective identities, depends on its ability to represent and symbolize diverse cultures in an appropriate and significant way.

\section{Conclusion}

The starting point of this paper was landmark buildings with - at least - one religious connotation, such as the Prussian City Palace in Berlin. As I have shown with regard to churches and mosques, religious landmark buildings use specific means of expression to stimulate the experience of the "numinous." They work with elements like height, emptiness, vastness, silence, etc., that is, features that are intensely experienced by the body. As a result, religious landmark buildings are often loaded with strong emotions and feelings of belonging or dis-belonging. However, the question why the discussions about constructing new (religious) landmark buildings, or reconstructing historical ones, are so highly emotionally charged can only be partly answered. As we have learnt from Paul Jones' work, landmark buildings are also im- 
portant cultural expressions of collective identities. In diverse societies, in which religious communities increasingly become fragmented and contested, the symbolic recognition of landmark projects appears to be especially crucial and a deeply political concern - as we have seen in the case of the Prussian City Palace in Berlin. Conceptualizing architecture with the help of Berger and Luckmann's sociology of knowledge as "material objectivations" that are products of human activity available both to their producers and others as tangible and visible elements of a common world, allows us to reflect upon buildings with regard to both their materiality and literal "thing-likeness" as well as to their symbolism.

\section{Bibliography}

Berger, P. L. and T. Luckmann (1967 [1966]). The Social Construction of Reality: A Treatise in the Sociology of Knowledge. London: Penguin Press.

Cencus Database (2011). https://ergebnisse.zensus2011.de/. Accessed September 26, 2017.

De Botton, A. (2006). The Architecture of Happiness. London: Penguin Books.

Delanty, G. and P. R. Jones (2002). "European Identity and Architecture." European Journal of Social Theory 5(4): 453-466.

Fokus Online (2017). “Hierarchie der Religionen? Buschkowsky schaltet sich in Berliner Kuppelkreuz-Kampf ein," Fokus Online. Without date. http:/ / www.focus.de/politik/deutschland/stadtschloss-hierarchieder-religionen-buschkowsky-schaltet-sich-in-berliner-kuppelkreuzkampf-ein_id_7177192.html. Accessed May 29, 2017.

Habermalz, C. (2017). “Der Tanz ums goldene Kreuz," Deutschlandfunk, June 6, 2017. http:/ / www.deutschlandfunk.de/berlin-der-tanz-ums-goldenekreuz.886.de.html?dram:article_id=387963. Accessed September 26, 2017.

Hennet, A.-I. (2007). “Die Berliner Schlossplatzdebatte - die Geschichte einer Identitätssuche," in: Schug, A. (Ed.). Palast der Republik: Politischer Diskurs und private Erinnerung. Berlin: Berliner Wissenschaftsverlag, p. 54-66. 
Jones, P. R. (2006). “The Sociology of Architecture and the Politics of Building: The discursive construction of Ground Zero." Sociology 40(3): 549-565.

Otto, R. (1936 [1917]). The Idea of the Holy. An Inquiry into the Non-Rational Factor in the Idea of the Divine and Its Relation to the Rational. London, Oxford University Press.

Otto, R. (2013 [1917]). Das Heilige: Über das Irrationale in der Idee des Göttlichen und sein Verhältnis zum Rationalen. München, C.H. Beck.

rbb (2017). "Grütters verteidigt geplantes Kreuz auf dem Humboldt-Forum," Rundfunk Berlin Brandenburg, May 20, 2017. https://www.rbbonline.de / kultur / beitrag/2017/05/diskussion-um-kuppelkreuz-aufhumboldt-forum.htm/listall=on/print=true.html. Accessed May 29, 2017.

Steets, S. (2015). Der sinnhafte Aufbau der gebauten Welt: Eine Architektursoziologie. Berlin: Suhrkamp.

- (2016). "Taking Berger and Luckmann to the Realm of Materiality: Architecture as a Social Construction." Cultural Sociology 10(1): 93-108.

Stiftung Zukunft Berlin (2017). "Schlosskuppel: bitte ohne Kreuz! ," Press release, May 18, 2017.

http: / / stiftungzukunftberlin.eu/fileadmin/szb / daten/Stiftung/Presse mitteilungen/17_05_18_SZB-

Pressemitteilung_Schlosskuppel_ohne_Kreuz.pdf. Accessed September 26, 2017.

Wohlrab-Sahr, M., U. Karstein and T. Schmidt-Lux (2009). Forcierte Säkularität: Religiöser Wandel und Generationendynamik im Osten Deutschlands. Frankfurt a. M. / New York: Campus.

Woodhead, L. (2016). “The Rise of 'no religion' in Britain: The emergence of a new cultural majority." Journal of the British Academy 4: 245-261. 